\title{
Sorption Recovery of Platinum (IV) from Hydrochloric Acidic Solutions in Presence of Iron (III), Copper (II) and Zinc
}

\author{
Olga N. Kononova* and Evgeniya V. Duba \\ Siberian Federal University \\ 79 Svobodny, Krasnoyarsk, 660041 Russia
}

Received 17.10.2015, received in revised form 26.11.2015, accepted 12.12.2015

The present work is devoted to sorption preconcentration of platinum (IV) in the presence of iron (III), copper (II) and zinc from chloride solutions on the samples of CYBBER - new samples of ion exchangers. The initial concentrations of platinum, iron and non-ferrous metal ions were 0.25, 0.5 and $2.0 \mathrm{mmol} / \mathrm{L}$, respectively. The acidity of the investigated solutions was $0.01-2 \mathrm{~mol} / \mathrm{L}$. It was shown that the ion exchangers possess high sorption ability to the noble metal ions, and allow the quantitative recovery of these ions. It was also found out that platinum can be isolated from the accompanying components by means of separate elution with $0.001 \mathrm{M} \mathrm{HCl}$ (iron ions), $0.5 \mathrm{M} \mathrm{HNO}_{3}$ (non-ferrous metal ions) and thiourea solution $(80 \mathrm{~g} / \mathrm{L})$ in $0.3 \mathrm{M} \mathrm{H}_{2} \mathrm{SO}_{4}$ (platinum ions).

Keywords: platinum, iron, copper, zinc, sorption, ion exchangers, hydrochloric acidic solutions.

DOI: $10.17516 / 1998-2836-2015-8-4-491-498$.

(c) Siberian Federal University. All rights reserved

* Corresponding author E-mail address: cm2@bk.ru 


\title{
Сорбционное извлечение платины (IV)
}

\section{из солянокислых растворов \\ в присутствии железа (III), меди (II) и цинка}

\author{
О.Н. Кононова, Е.В. Дуба \\ Сибирский федеральный университет \\ Россия, 660041, Красноярск, пр. Свободный, 79
}

Исследовано сорбционное концентрирование платины (IV) в присутствии железа (III), меди (II) и цинка из хлоридных растворов на новых образиах ионитов марки CYBBER. Исходные концентрации ионов платины, железа, меди и иинка составили соответственно 0.25, 0.5 и 2.0 ммоль/л. Кислотность исследуемых растворов 0.01 - 2 моль/л. Показана высокая сорбционная способность исследуемых ионитов к ионам благородного металла, что позволяет осуществить их количественное извлечение. Установлено, что платину можно отделить от сопутствующих компонентов путем раздельного элюирования при помощи $0.001 \mathrm{M} \mathrm{HCl}$ (ионь железа), $0.5 \mathrm{M} \mathrm{HNO}_{3}$ (ионы иветных металлов) и раствора тиомочевины (80 г/л) в $0.3 \mathrm{M} \mathrm{H}_{2} \mathrm{SO}_{4}$ (ионы платины).

Ключевые слова: платина, железо, медь, иинк, сорбиия, иониты, солянокислые растворы.

\section{Introduction}

In recent years the industrial consumption of platinum group metals (PGM) has been substantially grown up, which is largely related to their unique physical and chemical properties. The industrial application of the PGM is getting broader as well [1, 2]. In Russia, the major sources of PGM are the sulfide copper-nickel ores from the Talnakh peninsula of Krasnoyarsk Region [1-3]. Therefore, after the processing of these ores and conversion of PGM into solution, the noble metals are accompanied with iron, copper, zinc, nickel, cobalt and other non-ferrous metal ions. In line with the primary sources, the secondary sources of PGM (spent automobile and chemical catalysts, electronic scrap, slag, cakes, dusts, etc.) are also actively applied in various industries [1-4].

The distinctive feature of all sources of PGM is their multielement composition, where the noble metals are micro components, whereas the accompanying metals are macro components $[1$, $3,4]$. The breakdown of these raw materials results in the low concentrations of noble metals in the obtained industrial solutions [1, 2, 4-6]. These solutions contain complex compounds of PGM, varied by their stability and chemical inertness [1, 2, 7-9]. It is known [1, 2, 7-10] that these complexes are also affected by aquation and hydrolysis processes, as well as by the so-called ageing, when the PGM solutions are kept with low acidity. For these reasons, the selective methods are essential for the successful isolation of noble metals and removal of accompanying components from such complex solutions. In particular, the sorption methods are promising for these purposes, given their efficiency, environmental safety and also compatibility with a variety of post-determination methods $[4-6,11-15]$. 
At present time the research in this field is focused on nitrogen-containing anion exchangers, which possess high sorption ability and good kinetic properties. These characteristics allow to recover even the trace amounts of PGM through their preconcentration, and also to remove the interfering components. As a result, the obtained PGM solutions have high purification grade [1, 11-14, 16].

Previously we have investigated the sorption of platinum from chloride and sulfate-chloride media on Purolite ion exchangers $[17,18]$. The present work is devoted to sorption preconcentration of platinum in the presence of iron (III), copper (II) and zinc from hydrochloric acidic solutions on the CYBBER - new, previously uninvestigated samples of ion exchangers.

\section{Materials and methods}

The CYBBER ion exchangers we took for investigation were synthesized by the SYNTEZ $\mathrm{NVK}_{\mathrm{K}}$ Company (St. Petersburg, Russia). Their physical-chemical characteristics are summarized in Table 1. Prior to use, all sorbents were prepared according to conventional procedures and transformed into the $\mathrm{Cl}^{-}$- (anion exchangers) or $\mathrm{H}^{+}$- forms (chelate ion exchanger) using $2 \mathrm{M} \mathrm{HCl}$.

The freshly prepared working solutions of platinum with concentration $0.25 \mathrm{mmol} / \mathrm{L}$ were obtained by dissolution of accurately weighed $\mathrm{H}_{2} \mathrm{PtCl}_{6}$ quantities in concentrated hydrochloric acid, with the subsequent diluting of the obtained solution with distilled water. As a result, the acidity of these solutions was 2 and $0.01 \mathrm{~mol} / \mathrm{L}$.

The solutions of accompanying copper (II) and zinc ions with concentrations $2.0 \mathrm{mmol} / \mathrm{L}$ were prepared from accurately weighed quantities $\mathrm{CuCl}_{2} \cdot 2 \mathrm{H}_{2} \mathrm{O}$ and $\mathrm{ZnCl}_{2}$ by their dissolution in 0.01 or $2 \mathrm{M} \mathrm{HCl}$. The iron (III) solution with concentration $0.5 \mathrm{mmol} / \mathrm{L}$ was prepared by dissolution of iron (III) chloride shot by $2 \mathrm{M} \mathrm{HCl}$ with subsequent precise determination of its concentration according to complexometric titration using sulfosalicylic acid as an indicator [19].

The concentration of platinum (IV) and accompanying ions in the contacting solutions was determined by a spectrophotometrical method: platinum was determined with $\mathrm{SnCl}_{2} \cdot 2 \mathrm{H}_{2} \mathrm{O}$ [8, 9], copper (II) as well as zinc - with PAR (4-(2-pyridylazo)resorcinol [20, 21], and iron (III) - with sulfosalicylic acid [19, 22].

The sorption of investigated ions was carried out under batch experiment conditions at a solid-toliquid phase ratio of 1:100 and temperature of $(20 \pm 1)^{\circ} \mathrm{C}$. The equilibrium time determined by special tests was $24 \mathrm{~h}$.

Table 1. Physical-chemical properties of macroporous ion exchangers CYBBER based on styrene divinylbenzene

\begin{tabular}{|c|l|c|c|c|c|c|}
\hline $\begin{array}{c}\text { Trade } \\
\text { name }\end{array}$ & Exchanger type & $\begin{array}{c}\text { Functional } \\
\text { group }\end{array}$ & $\begin{array}{c}\text { Exchange capacity in the } \\
\mathrm{Cl}^{-} \text {-form }\left(\mathrm{H}^{+} \text {-form }\right), \mathrm{mmol} / \mathrm{g}\end{array}$ & Moisture, \% & $\begin{array}{c}\text { Swelling } \\
\text { grade, } \%\end{array}$ & $\begin{array}{c}\text { Working } \\
\mathrm{pH} \text { range }\end{array}$ \\
\hline AX 400 & $\begin{array}{l}\text { Strong base anion } \\
\text { exchanger }\end{array}$ & QAB & 1.20 & 44 & 15 & $0-14$ \\
\hline ALX 220 & $\begin{array}{l}\text { Weak base anion } \\
\text { exchanger }\end{array}$ & TAG & 1.50 & 50 & 21 & $0-8$ \\
\hline CRX 210 & Chelating resin & IDAA & $(1.12)$ & 55 & 20 & $1-6$ \\
\hline
\end{tabular}

QAB - quaternary ammonia base; TAG - tertiary amino-groups; IDAA - iminodiacetic acid. 
The efficiency of sorption recovery was estimated by means of the recovery degree $(R, \%)$ and the distribution coefficient $(D)$, which were calculated as follows:

$$
\begin{aligned}
& R=\frac{C_{0}-C_{e q}}{C_{0}} \cdot 100 \% ; \\
& D=\frac{W E C}{C_{e q}},
\end{aligned}
$$

where $C_{0}$ and $C_{e q}$ are the initial and equilibrium molar concentrations of metal ions, respectively; WEC $(\mathrm{mmol} / \mathrm{g})$ is working exchange capacity of ion exchanger towards the recovered metal ions. The latter was calculated from the equation:

$$
W E C=\frac{\left(C_{0}-C_{e q}\right) \cdot V}{m},
$$

where $V(\mathrm{~L})$ is volume of the contacting solution and $m(\mathrm{~g})$ is resin mass.

The separation possibilities for metal ions were estimated by means of separation coefficients $(S)$ :

$$
S=\frac{D_{P t}}{D_{M e}}
$$

where $D_{P t}$ is the distribution coefficient of platinum and $D_{M e}$ is the distribution coefficient of accompanying ion.

The elution of investigated ions after their recovery from solution on ion exchangers was carried out by means of $0.001 \mathrm{M} \mathrm{HCl}$ (desorption of iron), $0.5 \mathrm{M} \mathrm{HNO}_{3}$ (desorption of copper and zinc) and thiourea solution $(80 \mathrm{~g} / \mathrm{L})$ in $0.3 \mathrm{M} \mathrm{H}_{2} \mathrm{SO}_{4}$ (desorption of platinum).

All the results were subjected to statistical processing according to conventional procedures. The average experimental error for 3 parallel runs was less than $6 \%$.

\section{Results and discussion}

As mentioned above, iron (III) and non-ferrous metal ions always interfere into the recovery of noble metals during their extraction from primary and secondary PGM sources. Taking into account that the most common media for industrial conditions is hydrochloric acidic media, the investigation of sorption preconcentration of platinum from hydrochloric acidic solutions in the presence of interfering ions is a matter of academic and practical interest.

The ionic state of platinum in weak and strong acidic chloride solutions was investigated in detail in works $[1,2,4,7,9,10]$. In these media, it is equally probable for platinum to exist in oxidation states $2+$ and $4+$. This is explained by the similar standard redox potentials in the systems $\left[\mathrm{PtCl}_{6}\right]^{2-/}\left[\mathrm{PtCl}_{4}\right]^{2-}$ $\left(\mathrm{E}^{0}=+0.726 \mathrm{~V}\right)$ и $\left[\mathrm{PtCl}_{4}\right]^{2-} / \mathrm{Pt}^{0}\left(\mathrm{E}^{0}=+0.780 \mathrm{~V}\right)[1]$.

Depending on acidity of the medium, the concentration of chloride ions and temperature, a variety of aqua- and aquahydroxochloride complexes of platinum (II) and platinum (IV) can be formed in aqueous solutions $[1,7,9,10]$.

The ionic state of iron (III) in strong acidic chloride media is represented mostly by chloroferrate (III) ions $\left[\mathrm{FeCl}_{4}\right]$. With the increase in $\mathrm{pH}$ value of solution to $2-3$, the formation of both cationic and 
anionic complexes takes place due to hydrolysis [8]: $\left[\mathrm{Fe}\left(\mathrm{H}_{2} \mathrm{O}\right)_{6}\right]^{3+},\left[\mathrm{Fe}\left(\mathrm{H}_{2} \mathrm{O}\right)_{5} \mathrm{OH}\right]^{2+},\left[\mathrm{Fe}\left(\mathrm{H}_{2} \mathrm{O}\right)_{4}(\mathrm{OH})_{2}\right]^{+}$, $\left[\mathrm{FeOHCl}_{3}\right]^{-},\left[\mathrm{Fe}(\mathrm{OH})_{2} \mathrm{Cl}_{2}\right]^{-}$.

The ionic state of copper (II) and zinc in chloride media depends on acidity of solution [8, 23]. Both non-ferrous metal ions can form complexes $\left[\mathrm{CuCl}_{4}\right]^{2-}$ and $\left[\mathrm{ZnCl}_{4}\right]^{2-}(1-6 \mathrm{M} \mathrm{HCl})$ or $\left[\mathrm{Cu}\left(\mathrm{H}_{2} \mathrm{O}\right)_{6}\right]^{2+}$, $\left[\mathrm{ZnCl}_{4}\left(\mathrm{H}_{2} \mathrm{O}\right)_{2}\right]^{2-},\left[\mathrm{Zn}\left(\mathrm{H}_{2} \mathrm{O}\right)_{6}\right]^{2+},[\mathrm{ZnCl}]^{-}$and $\left[\mathrm{ZnCl}_{2}\right]^{0}(0.001-0.01 \mathrm{M} \mathrm{HCl})$.

Therefore, based on ionic states of components investigated, it can be concluded that the anion exchangers can be used for their sorption recovery and that the slight susceptibility of iron (III), copper (II) and zinc to hydrolysis offers prospects for their separation by elution.

We have preliminary studied the sorption ability of investigated ion exchangers during the recovery of components from individual solutions at $\mathrm{HCl}$ concentrations range of $0.001-4 \mathrm{~mol} / \mathrm{L}$. It was determined that the recovery of platinum (IV) ions was practically complete, with no dependence on acidity of the contacting solution. Almost the same sorption ability of the ion exchangers was demonstrated towards the iron (III) ions. As for the sorption of non-ferrous metal ions, we have revealed that copper (II) ions were extracted only from strong acidic solutions, whereas zinc ions were recovered only from weak acidic media. Such a behavior is undoubtedly related to the ionic states of copper (II) and zinc. Since the strong acidic media are common for industrial conditions, the zinc ions can be separated from the other ions directly on the sorption stage.

Table 2 contains data on platinum (IV) recovery from strong acidic chloride solutions in the presence of accompanying components. It can be seen from these data that the ion exchangers investigated maintain their high sorption ability to noble metal ions. The sorbents also exhibit high affinity to iron (III) by extracting of more than $80 \%$ of these ions. However, the recovery of copper (II) does not exceed $20 \%$. The selectivity of ion exchangers can be visualized in the following descending order:

$$
\mathrm{Pt}(\mathrm{IV})>\mathrm{Fe}(\mathrm{III})>\mathrm{Cu}(\mathrm{II})>\mathrm{Zn}(\mathrm{II}) .
$$

It is known $[24,25]$ that ion exchanger is normally more selective to ions with greater charge and smaller ionic radius. Since the ionic radii of Pt (IV), Fe (III) and Cu (II) are 0.055, 0.064 and $0.096 \mathrm{~nm}$

Table 2. Sorption of platinum (II, IV) from strong acidic chloride solutions in the presence of iron (III), copper (II) and zinc on ion exchangers investigated $\left(\mathrm{C}_{0}(\mathrm{HCl})=2 \mathrm{~mol} / \mathrm{L} ; \mathrm{C}_{0}(\mathrm{Pt})=0.25 \mathrm{mmol} / \mathrm{L} ; \mathrm{C}_{0}(\mathrm{Cu})=\mathrm{C}_{0}(\mathrm{Zn})=2 / 0\right.$ $\mathrm{mmol} / \mathrm{L}$ )

\begin{tabular}{|c|c|c|c|c|}
\hline \multirow{2}{*}{ Trade name } & Parameter & $\begin{array}{c}\text { Pt (II, IV) in presence } \\
\text { of Fe (III), Cu (II) } \\
\text { and Zn }\end{array}$ & $\begin{array}{c}\text { Fe (III) in presence } \\
\text { of Pt (II, IV), Cu (II) } \\
\text { and Zn }\end{array}$ & $\begin{array}{c}\text { Cu (II) in presence } \\
\text { of Pt (II, IV), Fe (III) } \\
\text { and Zn }\end{array}$ \\
\hline \multirow{2}{*}{ AX 400 } & R, \% & $95 \pm 5$ & $82 \pm 4$ & $14 \pm 1$ \\
\cline { 2 - 5 } & $\lg \mathrm{D}$ & $4.4 \pm 0.27$ & $1.7 \pm 0.11$ & $2.3 \pm 0.14$ \\
\hline \multirow{2}{*}{ ALX 220 } & $\mathrm{R}, \%$ & $95 \pm 5$ & $82 \pm 4$ & $20 \pm 2$ \\
\cline { 2 - 5 } & $\lg \mathrm{D}$ & $4.5 \pm 0.27$ & $1.7 \pm 0.11$ & $2.5 \pm 0.15$ \\
\hline \multirow{2}{*}{ CRX 210 } & $\mathrm{R}, \%$ & $77 \pm 4$ & $81 \pm 4$ & $12 \pm 1$ \\
\cline { 2 - 5 } & $\lg \mathrm{D}$ & $3.5 \pm 0.21$ & $1.6 \pm 0.11$ & $2.1 \pm 0.12$ \\
\hline
\end{tabular}


[26], respectively, we can assume that selectivity of ion exchangers is higher to double charged chloride complexes of platinum.

The separation coefficients of platinum and accompanying ions for the resins investigated are shown in Table 3. It can be seen that these values are greater than 1, pointing out to the possibility of separation of the extracted ions.

Furthermore, we have investigated the separation of platinum, iron as well as non-ferrous metal ions after their sorption on ion exchangers studied. It was carried out by separate elution. The results are represented in Table 4.

Initially, the iron (III) ions were removed by treatment of resins with $0.001 \mathrm{M} \mathrm{HCl}$ at $50^{\circ} \mathrm{C}$. Since iron (III) ions at $\mathrm{pH}=3$ easily undergo hydrolysis $[8,23]$, their desorption proceeds completely within $2 \mathrm{~h}$, i.e. with $\sim 100 \%$ degree of iron (III) recovery.

Given that copper (II) ions are recovered on the investigated resins to no more than $20 \%$ (Table 2), it was enough to wash the ion exchangers by $0.5 \mathrm{M} \mathrm{HNO}_{3}$ at once for their complete removal. After that, the elution of platinum by thiourea solution $(80 \mathrm{~g} / \mathrm{L})$ in $0.3 \mathrm{M} \mathrm{H}_{2} \mathrm{SO}_{4}$ was carried out, as such solutions are conventional desorption agents for noble metals [1,9]. As a result, $\sim 95-96 \%$ of platinum was eluted from the ion exchangers, i.e. it was the quantitative desorption.

Therefore, the investigated CYBBER ion exchangers can be recommended for technological schemes of the recovery of platinum in the presence of iron and non-ferrous metal ions from industrial hydrochloric acidic solutions.

Table 3. Separation coefficients of platinum (II, IV) and interfering ions during their sorption from strong acidic chloride solutions $\left(\mathrm{C}_{0}(\mathrm{HCl})=2 \mathrm{~mol} / \mathrm{L} ; \mathrm{C}_{0}(\mathrm{Pt})=0.25 \mathrm{mmol} / \mathrm{L} ; \mathrm{C}_{0}(\mathrm{Cu})=\mathrm{C}_{0}(\mathrm{Zn})=2 / 0 \mathrm{mmol} / \mathrm{L}\right)$

\begin{tabular}{|c|c|c|}
\hline \multirow{2}{*}{ Trade name } & \multicolumn{2}{|c|}{ Separation coefficients of Pt (II, IV) towards } \\
\cline { 2 - 3 } & Fe (III) & $\mathrm{Cu}(\mathrm{II})$ \\
\hline AX 400 & 5 & 137 \\
\hline ALX 220 & 4 & 91 \\
\hline CRX 210 & 2 & 34 \\
\hline
\end{tabular}

Table 4. Desorption of platinum and accompanying ions after their sorption on ion exchangers investigated. Sorption was carried out from $2 \mathrm{M} \mathrm{HCl}$ solution at $\mathrm{C}_{0}(\mathrm{Pt})=0.25 \mathrm{mmol} / \mathrm{L} ; \mathrm{C}_{0}(\mathrm{Cu})=\mathrm{C}_{0}(\mathrm{Zn})=2 / 0 \mathrm{mmol} / \mathrm{L}$

\begin{tabular}{|c|c|c|c|c|c|c|c|c|c|}
\hline \multirow{3}{*}{ Desorption agent } & \multicolumn{9}{|c|}{ Desorption degree ( $\%$ ) for } \\
\hline & \multicolumn{3}{|c|}{ Pt recovery from } & \multicolumn{3}{|c|}{ Fe recovery from } & \multicolumn{3}{|c|}{$\mathrm{Cu}$ recovery from } \\
\hline & 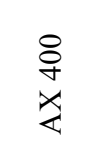 & 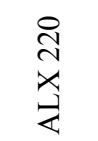 & 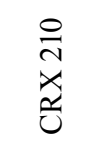 & $\begin{array}{l}8 \\
\stackrel{+}{+} \\
\text { x }\end{array}$ & 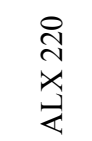 & 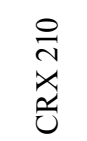 & $\begin{array}{l}8 \\
\stackrel{+}{+} \\
x \\
\gtrless\end{array}$ & 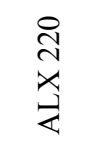 & $\begin{array}{l}\stackrel{0}{\sim} \\
\underset{x}{\approx}\end{array}$ \\
\hline $0.001 \mathrm{M} \mathrm{HCl}$ at $50^{\circ} \mathrm{C}$ & - & - & - & $\sim 100$ & $\sim 100$ & $\sim 100$ & - & - & - \\
\hline $0.5 \mathrm{M} \mathrm{HNO}_{3}$ & - & - & - & - & - & - & $\sim 100$ & $\sim 100$ & $\sim 100$ \\
\hline Thiourea $(80 \mathrm{~g} / \mathrm{L})$ in $0.3 \mathrm{M} \mathrm{H}_{2} \mathrm{SO}_{4}$ & $95 \pm 5$ & $95 \pm 5$ & $96 \pm 4$ & - & - & - & - & - & - \\
\hline
\end{tabular}




\section{Conclusions}

Sorption preconcentration of platinum (IV) from strong and weak acidic chloride solutions was investigated in the presence of accompanying iron (III), copper (II) and zinc ions on new samples CYBBER ion exchangers. It was shown that the ion exchangers investigated reveal the highest selectivity towards platinum, extracting it to $\sim 100 \%$. As for the accompanying ions, the greater affinity of the sorbents was revealed to iron (III) ions that were recovered to more than $80 \%$. The recovery degree of copper (II) ions from strong acidic solutions did not exceed $20 \%$, whereas zinc ions, owing to their ionic state, were not extracted from strong acidic media on the investigated resins.

The obtained results allow us to isolate zinc on sorption stage, and to separate the remaining studied components by their separate elution. Using $0.001 \mathrm{M} \mathrm{HCl}$ (for iron) and $0.5 \mathrm{M} \mathrm{HNO}_{3}$ (for copper) as the desorption agents, it is feasible to completely remove these ions from the resins. Then the platinum desorption was carried out by thiourea solution $(80 \mathrm{~g} / \mathrm{L})$ in $0.3 \mathrm{M} \mathrm{H}_{2} \mathrm{SO}_{4}$. As a result, the complete platinum extraction was achieved. Therefore, the CYBBER ion exchangers investigated can be recommended for application in technological processes for platinum recovery from industrial hydrochloric acidic solutions in presence of accompanying components.

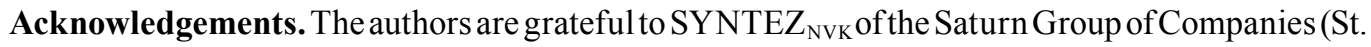
Petersburg) and to A.V. Barbanov personally for the resin samples kindly provided for investigation.

\section{References}

1. Zolotov Y.A., Varshal G.M., Ivanov V.M. Analytical chemistry of platinum group metals. Moscow: Editorial URSS, 2003. 592 p. (In Russ.)

2. Buslaeva T.M. Chemistry and technology of platinum group metals. Moscow: Nauka, 1999. 392 p. (In Russ.)

3. Kotlyar Y.A., Meretukov M.A., Strizhko L.S. Metallurgy of noble metals. Moscow: MISIS, 2005. 393 p. (In Russ.)

4. Al-Bazi S.J., Chow A. Platinum metals - solution chemistry and separation methods (ion exchange and solvent extraction). Talanta 1984. Vol. 31. P.815 - 836.

5. Angelidis T.N., Skouraki E. Preliminary studies of platinum dissolution from a spent industrial catalyst. Applied Catalysis A: general 1996. Vol. 142. P. 387 - 392.

6. Barahat M.A., Mahmoud M.H.H. Recovery of platinum from spent catalyst. Hydrometallurgy 2004. Vol. $72(3-4)$, P. $179-184$.

7. Beamish F.E. The analytical chemistry of the noble metals. Oxford: Pergamon Press, 1966. $702 \mathrm{p}$.

8. Cotton F.A., Wilkinson C. Advanced inorganic chemistry. A comprehensive text. New York: Wiley, 1969. $582 \mathrm{p}$.

9. Ginzburg S.I., Ezerskaya V.I., Prokofieva I.V., Shlenskaya Y.I., Belskiy N.K. Analytical chemistry of platinum group metals. Moscow: Nauka, 1975. 615 p. (In Russ.)

10. Sinitsyn N.M., Buslaeva T.M. Chemistry of complex halides of platinum group metals. Moscow: Rosvuznauka, 1992. 79 p. (In Russ.)

11. Bernardis F.L., Grant R.A., Sherrington D.C. A review of methods of separation of the platinum-group metals through their chlorocomplexes. Reactive and Funktional Polymers 2005. Vol. 65. P. $205-217$.

$$
-497-
$$


12. Els E.P., Lorenzen I., Aldrich C. The adsorption of precious metals and base metals on a quaternary ammonium group ion exchange resin. Minerals Engineering 2000. Vol. 13. P. 401 - 414.

13. Bogdanov V.I., Gorbatova L.D., Grokhovskiy S.V. New process in affinage of platinum group metals. Tsvetnye Metally 2001. Vol. 9 - 10. P. 33 - 37. (In Russ.)

14. Liu P., Liu G.-F., Chen D.-L., Cheng S.-Y., Tang N. Adsorption properties of Ag (I), Au (III), $\mathrm{Pd}$ (II) and Pt (IV) ions on commercial 717 anion exchange resin. Transaction of the Nonferrous Metals Society of China 2009. Vol. 19 (6). P. 1509 - 1513.

15. Pechenyuk S.I. Study of sorption of anionic complexes of platinum group metals. Vestnik Kolskogo Nauchnogo Zentra RAN 2013. Vol. 2. P. 64 - 74. (In Russ.)

16. Friss C. Selective ion exchange resins and their application in hydrometallurgy. Proceedings of the $1^{\text {st }}$ International Congress "Non-Ferrous Metals of Siberia", Krasnoyarsk, 2009. P. 578 - 581.

17. Kononova O.N., Melnikov A.M., Borisova T.V., Krylov A.S. Simultaneous ion exchange recovery of platinum and rhodium from chloride solutions. Hydrometallurgy 2011. Vol. 105. P. 341 349 .

18. Kononova O.N., Melnikov A.M., Borisova T.V. Simultaneous sorption recovery of platinum and rhodium from sulfate-chloride solutions. Hydrometallurgy 2012. Vol. 117 - 118. P. $101-107$.

19. Umland F., Janssen A., Thierig D., Wünsch G. Theorie und praktische Anwendung von Komplexbildnern. Frankfurt/Main: Akademische Verlagsgesellschaft, 1971. 535 p.

20. Zhivopistsev V.P., Seleznyova V.A. Analytical chemistry of zinc. Moscow: Nauka, 1975. 238 p. (In Russ.)

21. Podchaynova V.I., Simonova L.N. Analytical chemistry of copper. Moscow: Nauka, 1990. 241 p. (In Russ.)

22. Marchenko Z., Balzezhak M. Spectrophotometrical methods in UV and visible ranges in inorganic analysis. Moscow: BINOM, 2007. 711 p. (In Russ.)

23. Remy H. Lehrbuch für anorganische Chemie. Leipzig: Akademische Verlagsgesellschaft Geest \& Portig K.-G., 1960. 1074 p.

24. Helfferich F. Ion exchange. New York: McGraw Hill, 1962. 481 p.

25. Kokotov Y.A., Pasechnik V.A. Ion exchange equilibrium and kinetics of ion exchange. Leningrad: Khimiya, 1979. 374 p. (In Russ.)

26. Baron N.M., Kvyast E.I., Podgornaya E.A., Ponomaryova A.M., Ravdel A.A., Timofeeva Z.N. Short handbook of physical-chemical quantities. Leningrad: Khimiya, 1967. 182 p. (In Russ.) 